\title{
STRATEGI BISNIS YANG BERORIENTASI KONSUMEN
}

\author{
EUIS DASIPAH \\ Universitas Winaya Mukti, Jl. Raya Bandung Sumedang, Sumedang \\ e-mail: euis_dasipah@yahoo.co.id
}

\begin{abstract}
Use of philosophy The concept in a company program is the business that is in the organization, not only those who are responsible for the sales department and also. Organizational development requirements to differentiate between users for several activities used to manage resources and performance required by project management, allow to develop and improve performance, create programs and develop strong programs, creating the fundamental performance. the market, develop a commitment to consumers throughout the organization.
\end{abstract}

Keywords: business strategy, consumer

\section{PENDAHULUAN}

Banyak perusahaan-perusahaan yang menetapkan kepuasan konsumen sebagai prioritas puncak, meningkatkan komunikasi dan pengetahuan konsumen, memperkuat dukungan pelayanan dan hubungan yang erat, dan mengimplikasikan falsafah yang berorientasi konsumen. Untuk mencapai tingkat kepuasan konsumen yang tinggi, diperlukan pemahaman tentang apa yang diinginkan oleh konsumen dan mengembangkan komitmen setiap orang yang berada dalam organisasi untuk memenuhi kebutuhan ini. Manajemen harus membangun budaya organisasi yang bisa memahami dan memenuhi kebutuhan konsumen.

Dewasa ini ekonomi nasional sedang mengalami transformasi yang pesat, dimana ada dua kekuatan yang mendasari perubahan - perubahan tersebut. Yang pertama adalah globalisasi, pertumbuhan perdagangan global dan persaingan internasional yang eksplosif. Tidak ada negara sekarang ini dapat terisolasi dari ekonomi dunia. Jika negara itu menutup pasarnya dari persaingan asing, penduduknya akan membayar lebih mahal untuk barang berkualitas lebih rendah. Tetapi jika negara itu membuka pasarnya, ia akan menghadapi persaingan ketat dan banyak usaha domestiknya akan menderita.

Kekuatan yang lain adalah perubahan teknologi. Dalam dekade ini terjadi kemajuan luar biasa dalam ketersediaan informasi dan kecepatan komunikasi, bahan - bahan baru, kemajuan biogenetika dan obat - obatan, keajaiban elektronika. Tiap orang yang biasa di toko dengan katalog akan menyaksikan produk baru tanpa henti. Beberapa sejarawan menyatakan bahwa sebagian besar perubahan sejarah didorong oleh teknologi. Pasar dewasa ini berubah dengan kecepatan yang luar biasa, selain globalisasi dan perubahan teknologi, kita menyaksikan suatu pergeseran kekuasaan dan perusahaan manufaktur ke pengecer raksasa, pertumbuhan dan penerimaan merek - merek toko yang pesat, bentuk bentuk eceran baru, meningkatkan kepekaan konsumen terhadap harga dan nilai, berkurangnya peran pemasaran dan periklanan masal, dan erosi kesetiaan pada merek yang membingungkan. Perubahan - perubahan ini membuat perusahaan kebingungan tentang setrategi. Untuk melindungi laba mereka, perusahaan berusaha dengan meminjam biaya, merekayasa ulang proses mereka, dan 
merampingkan tenaga kerja mereka. Bahkan banyak perusahaan yang mungkin gagal untuk meningkatkan pendapatan mereka jika mereka tidak memiliki visi pemasaran dan keahlian pemasaran.

Pemasaran adalah suatu proses yang teratur dan jelas untuk memikirkan dan merencanakan pasar. Proses ini dimulai dengan riset pasar untuk mengerti dinamikanya. Pemasar menggunakan riset untuk mengidentifikasi peluang pasar yaitu, untuk menemukan individu atau kelompok orang dengan kebutuhan yang tidak terpenuhi atau suatu minat laten pada suatu produk atau jasa. Proses pemasaran mencakup mensegmentasi pasar dan memilih pasar sasaran yang dapat secara unggul dipuaskan oleh perusahaan. Perusahaan harus memformulasikan suatu strategi luas dan mendefinisikan suata bauran pemasaran yang spesifik dan rencana tindakan untuk mengoptimumkan kinerja jangka panjangnya. Perusahaan membentuk satu set kendali sehingga perusahaan dapat mengevaluasi. Proses pemasaran dapat diterapkan lebih dari sekedar barang dan jasa. Segala sesuatu dapat dipasarkan, termasuk ide, kejadian, organisasi, tempat, dan kepribadian. Namun, penting untuk menekankan bahwa pemasaran tidak dimulai dengan suatu produk atau penawaran, tetapi dengan suatu pencarian peluang dipasar.

\section{METODE PENELITIAN}

Penelitian menggunakan metode deskriptif untuk menjelaskan faktorfaktor yang mempengaruhi kepuasan konsumen sampai dengan tahap-tahap proses pembelian.

\section{HASIL DAN PEMBAHASAN}

\section{A. Faktor-Faktor yang Mempengaruhi Kepuasan Konsumen}

Perusahaan yang sukses dapat memuaskan konsumen mereka. Dengan perkataan lain, konsumen yang tidak puas akan mempengaruhi bisnis secara negatif. Perusahaan-perusahaan Amerika yang mempunyai reputasi sangat baik dalam memuaskan konsumen diantaranya adalah American Airlines. Banyak perusahaan lain dipenjuru dunia sangat berhasil dalam membuat konsumen mereka senang dan puas. Perusahaan mobil Jepang dalam pasar global memiliki performa yang kuat dalam memuaskan konsumen. Kesuksesan Honda dengan Acura Legend-nya di Eropa yang mendominasi segmen pasar mobil mewah impor, membuktikan nilai mutu rancanngan produk yang tinggi untuk memuaskan preferensi konsumen. Saat ini sejak kepiawaian Honda dalam memasuki segmen pasar ini, Honda merupakan saingan kuat bagi Mercedes-Benz, BMW, dan merkmerk Eropa lainnya.

Pemuasan konsumen harus disertai dengan pemantauan terhadap kebutuhan dan keinginan mereka. Mengidentifikasi atribut produk dan dukungan pelayanan yang dianggap penting oleh para pembeli pada saat mereka membeli dan menggunakan produk tersebut merupakan tujuan manajemen. Kepuasan konsumen dipengaruhi oleh system pengiriman produk, performa produk atau jasa, citra perusahaan /produk/merk, nilai harga yang dihubungkan dengan nilai yang diterima konsumen, prestasi para karyawan, keunggulan dan kelemahan para pesaing.

Memahami kebutuhan dan keinginan konsumen adalah hal penting yang mempengaruhi kepuasan mereka. Pengaruh kepuasan memperlihatkan bagaimana sebaiknya perusahaan bersaing di pasar. Kita tahu bahwa konsumen yang tidak 
puas akan memberitakan dua kali lebih hebat kepada orang lain tentang pengalaman buruknya, sedangkan konsumen yang puas akan memberitahukan tentang hal yang terbaik. Hasil penelitian menunjukkan bahwa jika keluhan konsumen dapat diselesaikan, konsumen akan melakukan pembelian enam kali lebih besar daripada jika konsumen tidak prnah mengeluh. Oleh karenanya perusahaan menempatkan nomor telepon bebas pulsa pada kemasan produknya untuk memudahkan konsumen memperoleh informasi produk dan jasa serta menyampaikan keluhan.

Konsumen yang puas merupakan asset yang sangat berharga, mereka menciptakan keunggulan daya saing bagi perusahaan. Jika biaya mendapatkan konsumen baru dan pengembangan hubungan jangka panjang yang menguntungkan dijumlahkan, akan merupakan investasi yang besar. Lebih dari itu konsumen yang puas akan terus melakukan pembelian terhadap merek yang pilihannya, jika produk tersebut memberikan nilai lebih disbanding merek saingan. Dengan demikian membangun nilai konsumen adalah hal yang penting.

\section{B. Organisasi Berfokus Konsumen}

Membangun hubungan antara konsumen, pemasok dan distributor diantara fungsi-fungsi dalam organisasi sangatlah penting untuk menjadi organisasi yang berfokus pada konsumen. Konsep penting yang mendasari proses ini adalah konsumen intern. Sebagai contoh pemasok dan fungsi produksi merupakan fungsi rancangan produk konsumen. Unit antarfungsional harus bekerja sama menuju kepuasan konsumen. Hal terpentingadalah setiap orang dalam organisasi mengatahui konsumen eksternal dan internalnya, dan memahami kebutuhan dan keinginan mereka.

Pemasaran adalah keseluruhan bisnis yang dilihat dari hasil akhirnya, yaitu dari sudut pandang pelanggan atau konsumen Keberhasilan usaha tidak ditentukan oleh produsen, dasar pemikiran pemasaran dimulai dari kebutuhan dan keinginan manusia. Keinginan adalah hasrat akan pemuas kebutuhan yang spesifik. Meskipun kebutuhan manusia sedikit, namun keinginan mereka banyak. Keinginan manusia terus dibentuk dan diperbaharui oleh kekuatan dan lembaga sosial. Permintaan adalah keinginan akan produk spesifik yang didukung oleh kemampuan dan kesediaan untuk membelinya. Keinginan menjadi permintaan jika didukung oleh daya beli.

Memahami perilaku konsumen dan "mengenal pelanggan" tidak pernah sederhana. Pelanggan mungkin menyatakan kebutuhan dan keinginan mereka namun bertindak sebaliknya. Mereka mungkin tidak memahami motivasi mereka yang lebih dalam. Mereka mungkin menanggapi pengaruh yang mengubah pemikiran mereka pada menit - menit terakhir. Bagaimanapun juga, pemasar harus memahami dan mempelajari keinginan, persepsi, preferensi, serta perilaku belanja dan pembelian pelanggan sasaran mereka.

Berdasarkan hal tersebut diatas ada tiga faktor yang mempengaruhi konsumen yaitu :

\section{Faktor Budaya}

Faktor budaya memiliki pengaruh yang luas dan mendalam terhadap perilaku. Peran budaya, sub budaya dan kelas sosial pembeli sangat penting. Budaya adalah penentu keinginan dan perilaku yang paling mendasar. Sebagaimana kita lihat, setiap budaya terdiri dari sub budaya yang lebih kecil sosiolisasi khusus bagi anggota - anggotanya. Sub-budaya terdiri dari bangsa, 
agama, kelompok ras, dan daerah geografis. Banyak sub-budaya yang membentuk segmen pasar penting, dan pemasar sering merancang produk dan program pemasaran yang disesuaikan dengan kebutuhan mereka.

Pada dasarnya semua masyarakat memiliki strata sosial. Strata tersebut kadang - kadang berbentuk sistem kasta dimana anggota kasta yang berbeda dibesarkan dengan peran tertentu dan tidak dapat mengubah keanggotaan kasta mereka. Kelas sosial tidak hanya mencerminkan penghasilan, tetapi juga indikator lain seperti pekerjaan, pendidikan, dan tempat tinggal. Kelas sosial menunjukkan preferensi dan merek yang berbeda dalam banyak hal, termasuk pakaian, perabot rumah tangga, kegiatan dalam waktu luang, dan mobil. Beberapa pemasar memusatkan usaha mereka pada satu kelas sosial.

\section{Faktor Sosial}

Sebagai tambahan atas faktor budaya, perilaku seorang konsumen dipengaruhi oleh faktor - faktor sosial seperti kelompok acuan, keluarga, serta peran dan status. Kelompok acuan terdiri dari semua kelompok yang memiliki pengaruh langsung ( tatap muka ) atau tidak langsung tarhadap sikap atau perilaku seseorang. Orang sangat dipengaruhi oleh kelompok acuan mereka. Kelompok acuan menghadapkan seseorang pada perilaku dan gaya hidup baru. Mereka juga mempengaruhi perilaku dan konsep pribadi seseorang. Dan mereka menciptakan tekanan untuk mematuhi apa yang mungkin mempengaruhi pilihan produk dan merek aktual seseorang.

\section{Faktor Psikologis}

Pilihan pembelian seseorang dipengaruhi oleh empat faktor utama motivasi, persepsi, pengetahuan, serta keyakinan dan pendirian. Motivasi seseorang memiliki banyak kebutuhan pada waktu tertentu. Beberapa kebutuhan bersifat biogenis, muncul dari tekanan biologis seperti lapar, haus, dan tidak nyaman. Kebutuhan lain bersifat psikogenis; mereka muncul dari tekanan biologis seperti kebutuhan akan pengakuan, penghargaan, atau rasa memiliki. Sebagian besar kebutuhan psikogenis tidak cukup kuat untuk memotivasi orang agar bertindak segera. Sesuatu kebutuhan akan menjadi motif jika ia didorong hingga mencapai tingkat intensitas yang memadai. Motif adalah kebutuhan yang cukup mendorong seseorang untuk bertindak. Dengan memuaskan kebutuhan tersebut ketegangan akan berkurang.

Persepsi seseorang yang termotivasi bertindak akan dipengaruhi oleh persepsinya terhadap situasi tertentu. Persepsi adalah proses bagaimana seseorang iadividu memilih, mengorganisasi, menginterpretasi masukan - masukan informasi untuk menciptakan dunia yang memiliki arti.

\section{Proses Pembelian dan Peranannya}

Untuk meraih pembeli, pemasar harus melewati bermacam - macam pengaruh yang mempengaruhi pembeli dan mengembangkan pemahaman bagaimana konsumen melakukan keputusan pembelian. Secara khusus, pemasar harus mengidentifikasi siapa yang membuat keputusan pembelian, jenis - jenis keputusan pembelian dan langkah - langkah dalam proses pembelian.

Perilaku pembelian adalah suatu hal yang mudah untuk mengidentifikasi pembelian dari banyak produk. Kita dapat membedakan lima peran yang dimainkan orang dalam keputusan pembelian. Pencetusan : Seorang yang pertama kali mengusulkan gagasan untuk membeli produk atau jasa. Pemberi pengaruh : Seseorang dengan pandangan atau saran yang mempengaruhi 
keputusan. Pengambil keputusan : seseorang yang memutuskan setiap komponen dari suatu keputusan pembelian yaitu apakah membeli, tidak membeli, bagimana membeli, dan dimana akan membeli. Pembeli : Orang yang melakukan pembelian yang sesungguhnya. Pemakai : Seseorang yang mengkonsumsi atau menggunakan produk atau jasa yang bersangkutan.

\section{Perilaku Konsumen}

Pengambilan keputusan konsumen berbeda - beda tergantung pada jenis keputusan pembeli. Pembeli yang rumit dan mahal mungkin melibatkan lebih banyak pertimbangan pembeli dan lebih banyak peserta. Disini membedakan empat jenis perilaku pembelian konsumen berdasarkan tingkat keterlibatan pembeli dan tingkat merek.

\section{Perilaku Pembelian Yang Rumit}

Konsumen terlibat dalam perilaku pembelian yang rumit saat mereka sangat terlibat dalam sebuah pembelian dan menyadari adanya perbedaan signifikan diantara berbagai merek. Keterlibatan yang tinggi didasari oleh fakta bahwa pembelian tersebut mahal, jarang dilakukan, dan berisiko. Setelah pembeli, konsumen mungkin mengalami disonasi atau ketidak sesuaian yang muncul dari pengamatan terhadap hal - hal yang mengganggu atau kabar tentang hal - hal yang menyenangkan. Konsumen akan waspada terhadap informasi yang membenarkan keputusannya.

\section{Perilaku Pembeli karena Kebiasaan}

Banyak produk dibeli dalam kondisi rendahnya keterlibatan konsumen dan tidak adanya perbedaan merek yang signifikan . Perilaku konsumen dalam kasus produk dengan keterlibatan rendah tidak melalui urutan umum keyakinan atau pendirian atau perilaku. Konsumen tidak mencari informasi tentang merek secara eksentif, mengevaluasi karakteristik mereka, dan mengambil keputusan yang penuh pertimbangan tentang merek apa yang akan dibeli. Sebaliknya, mereka menjadi penerima informasi pasif pada saat mereka menonton televisi atau melihat iklan dimedia cetak. Jadi bagi produk dengan keterlibatan rendah, proses pembelian dimulai dengan keyakinan merek yang dibentuk oleh pemahaman pasif, dilanjutkan oleh perilaku membeli, dan kemudian mungkin diikuti oleh evaluasi.

\section{Perilaku Pembeli Yang mencari Variasi}

Beberapa situasi pembelian ditandai oleh keterlibatan konsumen yang rendah namun perbedaan merek yang signifikan. Dalam situasi ini konsumen sering melakukan perpindahan merek. Perpindahan merek terjadi karena variasi dari pada ketidakpuasan.

Pimpinan pasar dan merek minor dalam jenis produk ini memiliki strategipemasaran yang berbeda. Pemimpin pasar akan berusaha mendorong perilaku pembelian karena kebiasaan dengan mendominasi rak - rak penjualan, menghindari kekurangan persediaan, dan sering mensponsori iklan - iklan untuk mengingatkan konsumen. Perusahaan penantang akan mendorong pencari variasi dengan menawarkan harga yang lebih rendah, penawaran khusus, kupon, contoh gratis, dan iklan yang menyaksikan alasan untuk mencoba sesuatu yang baru.

\section{E. Tahap - Tahap Proses Pembelian}

Perusahaan yang cerdik melakukan riset atas proses keputusan pembelian yang ada dalam jenis produk mereka. Mereka menanyai konsumen kapan mereka pertama kali mengenal kategori dan merek produk tersebut, dan apakah keyakinan 
merek mereka, seberapa besar mereka terlibat dengan produk yang bersangkutan, bagaimana mereka melakukan pemilihan merek, dan seberapa puas mereka setelah membeli.Konsumen melalui lima tahapan dalam proses pembelian sebuah produk yaitu

Pengenalan Masalah. Proses pembelian dimulai saat pembeli mengenali sebuahmasalah atau kebutuhan. Pembeli merasakan perbedaan antara keadaan aktualnya dengan keadaan yang diinginkannya. Kebutuhan tersebut dapat dicetuskan oleh rangsangan internal atau eksternal. Pemasar perlu mengidentifikasi keadaan yang memicu kebutuhan tertentu. Dengan mengumpulkan informasi dari sejumlah konsumen, pemasar dapat mengidentifikasi rangsangan yang paling sering membangkitkan minat akan suatu jenis produk. Pemasar kemudian dapat mengembangkan strategi pemasaran yang memicu minat konsumen.

Pencarian Informasi. Konsumen yang tergugah akan mengurangi pencarian informasi. Yang menjadi minat utama pemasar adalah sumber - sumber informasi utama yang menjadi pemicu konsumen dan pengaruh relatif tiap sumber tersebut terhadap keputusan pembelian selanjutnya.

Evaluasi Alternatif. Tidak ada proses evaluasi tunggal yang sederhana yang digunakan oleh semua konsumen atau oleh satu konsumen dalam semua situasi pembelian. Terdapat beberapa proses evaluasi keputusan, dan model yang terbaru memandang proses evaluasi konsumen sebagai proses yang berorientasi kognitif. Yaitu, mereka menganggap konsumen membentuk penilaian atas produk terutama berdasarkan kesadaran dan risiko.

Keputusan Pembelian. Konsumen membentuk preferensi atas merek merek dalam kumpulan pilihan. Konsumen juga mungkin membentuk niat preferensi atas merek - merek dalam kumpulan. Konsumen juga mungkin membentuk niat untuk membeli produk yang paling disukai. Namun, dua faktor dapat berada diantara niat pembeli dan keputusan pembelian. Keputusan konsumen untuk memodifikasi, menunda, atau menghindari suatu keputusan pembelian sangat dipengaruhi oleh risiko yang dirasakan. Besarnya risiko berbeda - beda menurut besarnya uang yang dipertaruhkan, besarnya ketidakpastian atribut, dan besarnya kepercayaan diri konsumen.

Perilaku Pembelian . setelah membeli suatu produk, konsumen akan mengalami tingkat kepuasan atau ketidak puasan tertentu. Tugas pemasar tidak berakhir saat produk dibeli, melainkan berlanjut hingga periode pasca pembelian. Pemasar harus memantau kepuasan pasca pembelian, tindakan pasca pembelian, dan pemakaian serta pembuangan pasca pembelian.

Kepuasan Pasca Pembelian . Setelah membeli suatu produk, seorang konsumen mungkin mendeteksi suatu kekurangan. Sebagian pembeli tidak menginginkan produk yang cacat, beberapa mengabaikan kekurangan tersebut, dan beberapa bahkan menganggapnya menambah nilai produk tersebut.

Kepuasan pembeli adalah fungsi seberapa dekat harapan pembeli atas suatu produk dengan kinerja yang dirasakan pembeli atas produk tertentu. Jika kinerja produk lebih rendah dari pada harapan pembeli, pembeli akan kecewa,. Jika ia sesuai harapan, pembeli akan puas. Jika ia melebihi harapan maka ia akan sangat puas. Perasaan - perasaan ini akan membedakan apakah pembeli akan membeli kembali produk tersebut dan membicarakan hal - hal yang menguntungkan atau tidak menguntungkan tentang produk tersebut pada orang 
lain. Derajat kepentingan kepuasan pasca pembelian menunjukkan bahwa penjual harus mengajukan klaim produk yang benar - benar menggambarkan kinerja produk.

Tindakan Pasca Pembelian. Kepuasan dan ketidakpuasan konsumen terhadap suatu produk akan mempengaruhi perilaku selanjutnya. Jika konsumen puas, ia akan menunjukkan kemungkinan yang lebih tinggi untuk membeli kembali produk tersebut. Pelanggan yang tidak puas bereaksi sebaliknya. Pemasar dapat dan harus mengambil langkah - langkah untuk meminimalkan jumlah ketidak puasan pasca pembelian konsumen. Komunikasi pasca pembelian dengan pembeli menunjukkan hasil dalam mengurangi pengembalian produk dan pembatalan pesanan.

Pemakaian dan Pembuangan Pasca pembelian. Pemasar juga harus memantau bagaimana pembeli memakai dan membuang produk. Jika konsumen membuang produk dalam lemari mereka, produk tersebut mungkin tidak begitu memuaskan, dan kabar dari mulut ke mulut tidak akan gencar. Jika mereka menjual atau menukarkannya produk tersebut, penjualan produk baru akan menurun. Jika konsumen menemukan kegunaan baru dari produk tersebut, pemasar harus mengiklankan kegunaan - kegunaan ini. Jika konsumen membuang produk, pemasar harus mengetahui bagaimana mereka membuangnya, terutama jika produk tersebut merusak lingkungan.

\section{KESIMPULAN DAN SARAN}

Mencapai kepuasan konsumen merupakan hal terpenting dalam memperoleh keunggulan daya saing. Dalam mencari strategi-strategi untuk memperoleh keunggulan bersaing, ada beberapa pertimbangan penting yang perlu diperhatikan : visi strategis sebagai peran penting dalam mengarahkan perusahaan, efektivitas peranan organisasi dalam strategi bisnis, dan penggunaan sistem informasi untuk memperoleh keunggulan strategis. Hal lain yang penting adalah inovasi produk dan jasa serta keterlibatan seluruh bagian organisasi dalam proses menuju organisasi pemasaran. Kepuasan konsumen merupakan tanggung jawab semua karyawan. Kepuasan konsumen merupakan fokus pemasaran. Penggunaan konsep pemasaran memberikan dasar pemikiran yang logis dalam pencapaian tujuan ini.

Perilaku konsumen dipengaruhi oleh empat faktor ; budaya. (budaya, subbudaya, dan kelas sosial), sosial (kelompok acuan, keluarga, serta peran dan status ), pribadi (usia, tahap siklus hidup, pekerjaan, keadaan ekonomi, gaya hidup, kepribadian, dan konsep diri), dan psikologis (motivasi, persepsi, pengetahuan, keyakinan, dan pendirian). Riset terhadap semua faktor - faktor ini dapat memberikan petunjuk seperti bagaimana cara merangkul dan melayani konsumen dengan lebih efektif.

Proses pembelian yang spesifik terdiri dari urutan kejadian berikut : pengenalan masalah, pencarian informasi, evaluasi alternatif, keputusan pembelian, dan peri laku pasca pembelian.

Teori konsumen untuk menjelaskan dan meramalkan produk - produk yang akan dipilih oleh konsumen pada tingkat pendapatan dan harga tertentu. Pendekatan yang digunakan dalam menganalisa penentuan pilihan konsumen ada tiga yaitu : pendekatan utilitas, curva indifferent, dan pendekatan atribut.Pada 
tingkat individu permintaan ditentukan oleh dua faktor yaitu : nilai dari cara mendapatkan dan menggunakan barang dan jasa.

\section{DAFTAR PUSTAKA}

Assauri, Sofjan., S.E, M.B.A. 1996. "M anajemen Pemasaran" Dasar, Konsep, dan Strategi. RajaGrafindo Persada, Jakarta.

Cravens David W. 1996. Pemasaran Strategis. Edisi Keempat Jilid 1 dan Jilid 2. Penerbit Erlangga Jakarta (Anggota IKAPI)

Kotler Philip. 2004. "Manajemen Pemasaran" Analisis, Perencanaan, Implementasi, dan Pengendalian, Salemba Empat, Jakarta.

Rahardja Prathama dan Manurung Mandala. 2002. Pengantar Ilmu Ekonomi. Lembaga Penerbit Fakultas Ekonomi Universitas Indonesia. Jakarta.

Soekartawi. 1996. Prinsip Dasar Manajemen Pemasaran Hasil-Hasil Pertanian Teori dan Aplikasi. Penerbit Rajawali Pers Jakarta. 